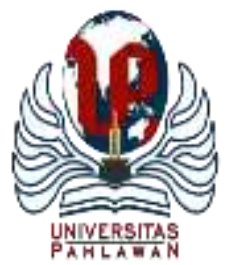

Edukatif : Jurnal Ilmu Pendidikan Volume 3 Nomor 6 Tahun 2021 Halm 3905 - 3918

EDUKATIF: JURNAL ILMU PENDIDIKAN

Research \& Learning in Education

https://edukatif.org/index.php/edukatif/index

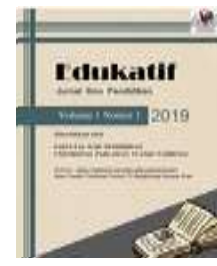

\title{
Pengembangan Instrumen Tes untuk Mengukur Kemampuan Problem Solving Siswa pada Materi Aritmatika Sosial
}

\author{
Nur Yuliani ${ }^{1 凶}$, Sitti Mania ${ }^{2}$, Dian Magfirah $^{3}$, Fitriani Nur $^{4}$, Suharti $^{5}$ \\ UIN Alauddin Makassar, Indonesia ${ }^{1,2,3,4,5}$

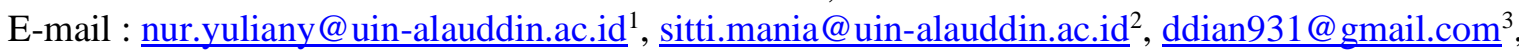 \\ fitrianinur@uin-alauddin.ac.id ${ }^{4}$, suharti.harti@uin-alauddin.ac.id ${ }^{5}$
}

\begin{abstract}
Abstrak
Permasalahan utama dalam penelitian ini ialah pembuatan produk berupa instrumen tes yang bermaksud untuk mengukur kemampuan memecahkan masalah para siswa. Proses penelitian ini mengadopsi rangkaian tahapan dari model pengembangan tipe formative evaluation. Informasi data didapatkan melalui observasi dan interview dengan menggunakan angket, tes, serta lembar validasi sebagai alat ukur/instrumennya. Data dianalisis hingga memenuhi kevalidan dan kepraktisan. Dari rangkaian penelitian, diperoleh bahwa produk instrumen tes yang sudah dikembangkan sudah valid dan praktis dengan perolehan skor validitas 0.78 serta 74\% dan $83 \%$ untuk skor kepraktisan. Jadi instrumen tes sudah dinyatakan layak untuk diaplikasikan.
\end{abstract}

Kata Kunci: instrument tes, pemecahan masalah, penelitian dan pengembangan.

\section{Abstract}

The main problem in this research is the manufacture of a product in the form of a test instrument which aims to measure students problem-solving abilities. This research process adopt a series of stages from the formative evaluation type development model. Data information is obtained through observation and interviews using questionnaires, tests, and validation sheets as measuring instruments. Data were analyzed to meet validity and practicality. From a series of studies, it was found that the product of the test instrument that had been developed was valid and practical with a validity score of 0.78 and $74 \%$ and $83 \%$ for practicality scores. So the test instrument has been declared suitable for application.

Keywords: instrument test, problem solving, research and development.

Copyright (c) 2021 Nur Yuliani, Sitti Mania, Dian Magfirah, Fitriani Nur, Suharti

$\triangle$ Corresponding author

Email : nur.yuliany@uin-alauddin.ac.id

DOI : https://doi.org/10.31004/edukatif.v3i6.1226 
3906 Pengembangan Instrumen Tes untuk Mengukur Kemampuan Problem Solving Siswa pada Materi Aritmatika Sosial - Nur Yuliani, Sitti Mania, Dian Magfirah, Fitriani Nur, Suharti

DOI: https://doi.org/10.31004/edukatif.v3i6.1226

\section{PENDAHULUAN}

Perkembangan IPTEK di masa sekarang sangat maju dan memberi keuntungan bagi manusia. Segala teknologi yang ada begitu mempermudah urusan-urusan individu, baik dalam lingkup pribadi maupun dunia kerja. Namun keuntungan ini justru memberi tuntutan bagi manusia untuk mempunyai keterampilan tertentu agar mereka bisa mengimbangi perkembangan ini (Hidayat, Syarif Rokhmat, 2017). Hal ini tidak lepas dari peran suatu Pendidikan yang menciptakan manusia-manusia berbobot.

Peningkatan bobot Pendidikan dalam negara kita diantaranya ialah penerapan kurikulum 2013 yang diupayakan oleh pemerintah. Kurikulum 2013 merupakan jawaban dari pemerintah atas tantangan abad ke-21. Amanat kurikulum 2013 dalam implementasi pendidikan harus memasukkan keterampilan abad ke-21 dalam pelaksanaan pembelajaran di sekolah. Menurut UNESCO, keterampilan dan kompetensi abad 21 diantaranya berpikir kritis, inovasi dan kreativitas, problem solving (menyelesaikan permasalahan), keterampilan lintas budaya dan sosial maupun literasi informasi (Masfuah, 2018). Selain itu, standar isi pendidikan dalam ranah keterampilan mengharuskan peserta didik agar mampu menunjukkan keterampilan berpikir mengenai kemajuan dari yang mereka pelajari saat di lingkungan sekolah. Matematika termasuk jajaran pelajaran yang masuk kategori wajib untuk diajarakan, dimulai tingkatan dasar yakni SD sampai tingkatan sekolah menengah yang memerlukan penguasaan sejak dini karena matematika sangat berpengaruh dalam pembentukan pola pikir para pelajar (Syaharuddin, 2016). Perkembangan kemampuan pelajar adalah berkat peran dari seorang pendidik yakni guru. Untuk mengetahui perkembangan atau tingkatan pengetahuan, kepiawaian, ataupun bakat mereka, bisa dilakukan atau diberikan evaluasi sejauh mana proses pembelajaran mencapai tujuan atau sasaran (Nursalam, 2016).

Persoalan yang lazimnya terjadi saat pembelajaran ialah peserta didik Nampak selalu membuat kesalahan ketika mengerjakan soal-soal yang belum rutin dan akhirnya mengakibatkan keterampilan mereka dalam memecahkan masalah menjadi rendah (Wahyuningrum, 2015). Berdasarkan hasil PISA terbaru tahun 2018 menyelenggarakan pengujian performa di bidang akademis anak-anak sekolahan secara rerata disetiap negara menunjukkan Indonesia (IND) menempati posisi di peringkat 73 dari 79 negara untuk bidang matematika dengan skor 379. Apabila disandingkan dengan skor rerata internasional sebesar 489, IND mempunyai jarak yang terbilang cukup jauh. Berdasarkan tolok ukur tersebut dapat menunjukkan letak IND pada aspek pendidikan dibanding negara lain, sehingga hasil PISA dapat menjadi salah satu informasi dalam mempersiapkan sistem sekolah yang lebih efektif untuk mempersiapkan peserta didik melanjutkan studi atau memasuki dunia kerja.

Matematika adalah salah satu mata pelajaran wajib di sekolah mulai dari jenjang sekolah dasar sampai jenjang sekolah menengah yang memerlukan penguasaan sejak dini karena matematika sangat berpengaruh dalam pembentukan pola piker peserta didik (Syahruddin, 2016). Perkembangan kemampuan peserta didik tidak lepas dari peranan seorang pendidik atau guru di sekolah. Untuk mengetahui perkembangan atau tingkat pengetahuan, keterampilan, bakat, dan kemampuan peserta didik dapat dilakukan dengan memberikan evaluasi sejauh mana proses pembelajaran mencapai tujuan atau sasaran (Nursalam, 2016).

Urgensi pelaksanaan evaluasi dalam pembelajaran sesungguhnya dapat dijumpai dalam Al-Qura'an. Salah satunya dalam Surah Al- Baqarah/ 2:31. Dengan arti "Dan dia mengajarkan kepada Adam nama-nama (benda) seluruhya, kemudian mengemukakannya kepada para Malaikat lalu berfirman : Sebutkanlah kepada$\mathrm{Ku}$ nama benda-benda itu jika kamu memang benar orang-orang yang benar". Ayat di atas memberikan petunjuk adanya suatu proses evaluasi, pembelajaran yang dilakukan Allah SWT terhadap Nabi Adam a.s. Maksud ayat tersebut untuk mengukur sejauh mana pengetahuan dari seluruh materi pembelajaran yang telah Allah berikan kepada Nabi Adam dengan cara mengemukakakan Kembali dihadapan para malaikat. Isyarata Al-QQUr'an tersebut menunjukkan perlunya evaluasi dalam pembelajaran memberikan pemahaman sekaligus petunjuk bahwa evaluasi pembelajaran menenmpati posisi yang urgen. 
3907 Pengembangan Instrumen Tes untuk Mengukur Kemampuan Problem Solving Siswa pada Materi Aritmatika Sosial - Nur Yuliani, Sitti Mania, Dian Magfirah, Fitriani Nur, Suharti

DOI: https://doi.org/10.31004/edukatif.v3i6.1226

Dalam melakukan evaluasi diperlukan suatu instrument tes yang memenuhi indicator instrumen tes yang baik dan valid dan dapat mengukur apa yang hendak diukur. Instrument es yang digunakan dalam penelitian ini adalah tes untuk mengukur kemampuan pemecahan masalah (problem solving). The National Council of Teacher of Mathematics menyatakan pentingnya pemecahan masalah pada kurikulum matematika yang seharusnya menjadi fokys sentral dalam kurikulum. Selain itu, keterampilan pemecahan masalah juga merupakan kompetensi abad 21 yang dimaksudkan kurikulum 2013 dalam impelementasi Pendidikan. Pentingnya kemampuan pemecahan masalah karena meliputi metode, prosedur, dan strategi dalam menyelesaikan permasalahan (Sumartini, 2016). Kemampuan pemecahan masalah merupakan usaha mencari jalan keluar dari suatu tujuan yang tidak begitu mudah segera dapat dicapai (Hidayat, Syarif Rokhmat, 2017).

Masalah yang sering terjadi dalam pembelajaran adalah peserta didik sering melakukan kesalahan dalam menyelesaikan soal-soal yang non rutin yang mengakibatkan kemampuan pemecahan masalah mereka rendah (Wahyuningrum, 2015). Berdasarkan hasil PISA terbaru tahun 2018 menguji performa akademis anak anak sekolah secara rata-rata disetiap negara menunjukkan Indonesia berada pada peringkat 73 dari 79 negara untuk bidang matematika dengan skor 379. Jika dibandingkan dengan skor rata-rata internasional sebesar 489, Indonesia memiliki jarak yang cukup jauh. Berdasarkan tolak ukur tersebut dapat menunjukkan posisi Indonesia di dunia Pendidikan disbanding dengan negara lain, sehingga hasil PISA dapat menjadi salah satu informasi dalam mempersiapkan system sekolah yeng lebih efektif untuk mempersiapkan peserta didik melanjutkan studi atau memasuki dunia kerja.

Pembelajaran di sekolah harusnya bisa mengarahkan para pelajar agar menumbuhkan dan memajukan kemampuan berpikir salah satunya dalam memecahkan masalah. Apabila pelajar telah memiliki keterampilan tersebut, berarti mereka akan mampu menganalisis sebuah masalah sehingga mampu membangun argumen yang dapat dipercaya dengan bukti. Secara sederhana, research and development mampu diartikan sebagai suatu cara dalam penelitian tang dengan sengaja, terstruktur, mempunyai target menemukan, manyebutkan, merenovasi, mengembangkan, memproduksi, mengevaluasi keefektifan sebuah produk, model, prosedur, serta jasa tertentu lebih bagus, efektif, baru, efisien, bermakna, dan juga produktif. (Putra, 2015). Van den Akker dan Plomp menjelaskan penelitian pengembangan didasarkan oleh 2 target/tujuan, yakni pengembangan untuk menghasilkan pola dari produk dan kedua perumusan beberapa saran metodologis terhadap gambaran produk serta uji pola produk bersangkutan.

Pengembangan model tessmer lazimnya juga dikenal model formative evaluation yakni Teknik uji yang sering kali digunakan dalam menentukan tingkat kualitas dari hasil pengembangan (Tessmer, 1993). Pada Ilmu sosial banyak dari ahli yang membekukan instrument pada beberapa keperluan pengukuran. Penelitian ini apabila menggunakan alat ukur yang baku ketika mengukur, maka mengumpulkan data harus melaporkan hasil pengujian pada kualitas ukur seseorang yang sudah membakukannya (Angriani, Andi Dian, 2018). Pada umumnya, alat ukur menentukan keberhasilan suatu pengamatan, karena data untuk uji hipotesis didapatkan dari alat ukur yang digunakan. Instrument yang menjadi alat mengumpulkan data perlu dengan serius dirancang serta dibuat dengan berbagai bentuk sehingga bisa menghasilkan sustu data empiris yang apa adanya (Arifin, 2013).

Pembelajaran dengan problem solving atau metode pemecahan masalah di sekolah dimaksudkan agar pelajar bisa berfikir yang seluas-luasnya dari daya tangkapnya hingga puncak maksimal. Metode pemecahan masalah merupakan cara mengajar yang menuntut para pelajar menggunakan nalar dalam menganalisa, menentukan sebab akibat kemudian menyimpulkan bahkan dengan menciptakan hukum-hukum atau kaidah teoritis (Sumardoyo, 2010). Pembelajaran dengan basis problem solving adalah metode pembelajaran yang direkomendasikan oleh pemerintah (Kemendikbud, 2013). Menurut Sutarno et al., (2017) bentuk keterampilan yang harus diberikan kepada siswa ialah keterampilan dalam memecahkan masalah atau problem solving. Pembelajaran tidak hanya ditujukan sebagai pengembangan pengetahuan semata, akan tetapi tetapi juga untuk 
3908 Pengembangan Instrumen Tes untuk Mengukur Kemampuan Problem Solving Siswa pada Materi Aritmatika Sosial - Nur Yuliani, Sitti Mania, Dian Magfirah, Fitriani Nur, Suharti

DOI: https://doi.org/10.31004/edukatif.v3i6.1226

mengembangkan keterampilan siswa, siswa dituntut untuk membangun dan menemukan pengetahuannya sendiria agar bisa memecahkan masalah (Sagita et al., 2018).

Terdapat empat indikator dalam kemampuan pemecahan masalah (problem solving), diantaranya: (1) you have to understand the problem, (2) make a plan, (3) carry out the plan, (4) look back on your work (Polya, 1945). Keempat indikator tersebut masing-masing memiliki subindikator yang akan dijadikan acuan dalam pengukuran kemampuan pemecahan masalah peserta didik. Pengumpulan informasi dan fakta-fakta dalam memecahkan suatu masalah tingkat lanjut dapat dilakukan dengan combining skills using imagination, developing models, carring out investigations, data analysis and inference (Butterworth, 2013). Menggunakan materi matematika yang menyangkut kehidupan sosial, terutama penggunaan mata uang dikenal dengan nama "Aritmatika Sosial".

Berdasarkan hasil observasi yang dilakukan di SMPN 2 Sungguminasa Kabupaten Gowa pada tanggal 1 Oktober 2019 melalui wawancara dengan salah satu guru matematika yaitu Ibu Sitti Fatimah, S.Pd yang mengajar pada kelas VII, Guru menyatakan bahwa dalam praktik mengajar, instrumen tes yang digunakan seringkali hanya berdasarkan pada soal-soal yang terdapat dalam buku. Sementara itu, hasil analisis buku yang dilakukan oleh (Wulandari, 2017) menunjukkan hanya ada 582 item soal mengenai pemecahan masalah (sekitar 33.64\% dari 1730 item soal) dalam buku siswa Kurikulum 2013. Jika guru hanya menggunakan soalsoal yang dipilih acak yang terdapat pada buku paket maka peluang para pelajar menyelesaikan soal atau instrumen tes kemampuan pemecahan masalah masih sangat kurang. Peserta didik tidak terbiasa dengan pembelajaran ataupun instrumen tes yang didesain khusus untuk mengembangkan kemampuan pemecahan masalah (problem solving). Hasil dari analisis buku mata pelajaran matematika yang dilakukan oleh (Hidayat, 2016) juga mengemukakan rerata tingkat kognitif untuk soal condong lebih tinggi di level pengetahuan, sementara level tentang penerapan juga penalaran yang masih pada kategori rendah. Kurikulum 2013 mengharapkan peserta didik memunculkan kepiawaian berpikir saat evaluasi pembelajaran, sehingga instrument bentuk tes tertulis yang disusun guru diharapkan bisa mengarahkan peserta didik menumbuhkan keterampilan tersebut. Kepiawaian memecahkan masalah bukan kepiawaian uang bisa didapat dengan instan, tapi perlu dibentuk dengan latihan serta kegiatan yang senantiasa dikerjakan terus menerus melalui proses pembelajaran dan juga melalui evaluasi yang tepat (Astuti, 2019).

Kurikulum 2013 mengharapkan peserta didik memunculkan kemampuan berpikir dalam evaluasi pembelajaran, sehingga instrument tes tertulis yang dibuat guru diharapkan mampu mengarahkan peserta didik untuk memunculkan keterampilan tersebut. Kemampuan pemecahan masalah matematis bukanlah kemampuan yang dapat diperoleh seketika, namun harus dibangun melalui latihan dan pembiasaan yang dilakukan secara terus menerus melalu proses pembelajaran dan juga melalui evaluasi yang tepat (Astuti, 2019). Pada tiap pembelajaran di setiap jenjang aka nada proses evaluasi. Dalam proses evaluasi tersebut merupakan hal penting untuk perkembangan kualitas Pendidikan dalam suatu negara terkhusus di Indonesia. Hal tersebut dijelaskan dalam UU SISDIKNAS No 20 Thn 2003 BAB XVI mengenai Evaluasi. Menurut (Sudijono, 2008) tujuan diadakannya evaluasi yaitu agar memperoleh data pembuktian yang akan dijadikan petunjuk untuk melihat sejauh mana kemampuan dan tingkat keberhasilan siswa mencapai tujuan pembelajaran. Saat proses evaluasi, seorang guru tidak lepas dari yang Namanya instrument. Menurut Arifin (2013) instrumen memiliki fungsi dan peran yang penting dalam mengetahui keefektifan pembelajaran. Selain itu, Mulyadi (2010) menyatakan proses evaluasi mencakup hal pengkuran dan tes. Ketika melakukan sebuah evaluasi, maka Pendidikan harus melakukan pengukuran dengan menggunakan alat yang disebut tes. S. Hamid Hasan dalam Arifin (2013) menyatakan bahwa tes merupakan alat pengumpulan data yang dibuat secara khusus.

Berdasarkan uraian di atas, peneliti tertarik untuk mengembangkan suatu instrument tes uraian yang mampu mengukur kemampuan pemecahan masalah (problem solving) peserta didik. Masalah matematika dalam bentuk soal uraian atau soal cerita lebih sulit dipecahkan oleh peserta didik dibandingkan dengan soal 
3909 Pengembangan Instrumen Tes untuk Mengukur Kemampuan Problem Solving Siswa pada Materi Aritmatika Sosial - Nur Yuliani, Sitti Mania, Dian Magfirah, Fitriani Nur, Suharti

DOI: https://doi.org/10.31004/edukatif.v3i6.1226

yang hanya melibatkan bilangan-bilangan atau soal-soal yang hanya terkait dengan perhitungan angka-angka (Angriani, 2018: 214). Tes uraian dianggap sebagai tes yang sesuai untuk mengatur kemampuan pemecahan masalah (Problem solving) peserta didik. Tes uraian yang bersifat subjektif dapat menghindari peserta didik menjawab dengan cara menebak karena menuntuk untuk menyampaikan, memilih, Menyusun dan memudahkan ide yang dimiliki dalam memecahkan masalah atau memperoleh jawaban secara kontekstual menggunakan matematika. Alat ukur berupa instrument tes yang dikembangkan sebagai instrument tes Latihan yang berisi pertanyaan yang menguji peserta didik dalam memecahkan masalah matematis. Penggunaan alat ukur yang tepat diharapkan mampu melatih peserta didik untuk terbiasa dalam mengerjakan soal-soal kemampuan pemecahan masalah sehingga keterampilan tersebut bisa menjadi modal untuk menghadapi berbagai situasi dan permasalahan di kehidupannya kelak.

\section{METODE PENELITIAN}

Penelitian yang diterapkan masuk dalam jenis penelitian dan pengembangan. Jenis ini juga biasanya disebut R\&D. Secara sederhana penelitian dan pengembangan menurut Putra (2011:67) mendefisikan sebagai penelitian yang secara sengaja, sistematis, bertujuan untuk mencari, temukan, merumuskan, memperbaiki, mengembangkan, menghasilkan, menguji keefektifan, strategi, model, efisien, produktif dan bermakna. Model yang diterapkan ialah model pengembangan dengan tipe formative evaluation (Tessmer, 1993). Tahapan yang dilalui ialah preliminary, yaitu tahap pengumpulan beberapa referensi yang berhubungan dengan pengembangan ini. Setelaha beberapa teori dan referensi sudah terkumpul, selanjutnya akan dilakukan kegiatan penentuan tempat dan subjek penelitian. Penentuan tempat dilakukan dengan cara menghubungi kepala sekolah dan guru mata pelajaran matematika di sekolah yang akan dijadikan lokasi uji coba. Selanjutnya peneliti akan melakukan wawancara terhadap guru matematika yang bersangkutan mengenai kurikulum pembelajaran yang ditetapkan di sekolah serta wawancara tentang bagaimana cara mengukur kemampuan siswa di sekolah. lalu self evaluation, dilakukan penilaian oleh diri sendiri terhadap desain instrument tes kemampuan problem solving yang akan dibuat oleh peneliti. Tahapan ini terdiri dari dua kegiatan yaitu tahap analisis dan tahap mendesain. Kemudian prototyping (memuat expert review, one to one, small group) pada tahap ini produk yang telah dibuat desain atau didesain akan dievaluasi. Hasil desain prototype yang dikembangkan atas dasar self evaluation diberikan pada pakar (expert review) dan siswa (oneto-one) secara parallel, kemudian pada small group. Tahap Field Test, pada tahap ini hasil revisi dari prototype II diujicobakan pada subjek uji coba penelitian dalam hal ini sebagai field test, yaitu siswa kelas VIII 9 SMPN 2 Sungguminasa dengan jumlah responden 38 siswa. Selain model, penelitian ini juga menerapkan desain alur tes model formative evaluation Tessmer. Siswa yang dijadikan sebagai obyek penelitian dari kelas IX SMP Negeri 2 Sungguminasa, Gowa.

Data dikumpulkan melalui observasi dan interview/wawancara, sementara instrument dalam mengumpulkan data menggunakan angket, lembar validasi, dan tes. Sebelum instrument digunakan, instrument harus divalidasi, oleh sebab itu setiap instrument harus memiliki lembar validasi. Teknik analisis data yang digunakan ialah Analisis Kevalidan instrument Tes oleh Ahli, untuk mengetagui kesepakatan para ahli digunakan indeks validitas yang diusulkan oleh Aiken dengan Indeks Aiken's V:

$$
\mathrm{V}=\frac{\sum S}{n(c-1)}
$$

Keterangan:

$$
\begin{aligned}
& \mathrm{s} \quad \mathrm{r}-\mathrm{Io} \\
& \mathrm{r} \quad \text { : Angka yang diberikan penilai } \\
& \mathrm{Io}: \text { Angka penilaian validitas terendah (dalam hal ini }=1 \text { ) } \\
& \mathrm{n} \quad \text { : Jumlah Penilai (rater) }
\end{aligned}
$$


3910 Pengembangan Instrumen Tes untuk Mengukur Kemampuan Problem Solving Siswa pada Materi Aritmatika Sosial - Nur Yuliani, Sitti Mania, Dian Magfirah, Fitriani Nur, Suharti

DOI: https://doi.org/10.31004/edukatif.v3i6.1226

c : Angka penilaian validitas tertinggi (dalam hal ini $=5$ )

Selanjutnya Analisis Kevalidan Butir Instrumen, Validiyas butir secara statistic dapat dianalisis berdasarkan jenis data yang ada. Untuk tes objektif dihitung menggunakan korelasi point biseral sedangkan tes subjektif menggunakan korelasi Pearson product moment. Perhitungan validasi menggunakan rumus korelasi product moment yaitu:

$$
\mathrm{r}=\frac{N \sum X Y-\left(\sum X\right)\left(\sum Y\right)}{\sqrt{\left(N \sum X^{2}-(\Sigma)^{2}\right) \sqrt{\left.N \Sigma Y^{2}-(\Sigma Y)^{2}\right)}}}
$$

Keterangan:

$\begin{array}{ll}\mathrm{R} & \text { : Koefisien Korelasi Pearson } \\ \mathrm{N} & \text { : Jumlah Peserta } \\ \sum \mathrm{X} & \text { : Jumlah skor } \mathrm{X} \\ \sum \mathrm{Y} & \text { : Jumlah Skor } \mathrm{Y} \\ \sum X^{2} & \text { : Jumlah Kuadrat Skor X } \\ \sum Y^{2} & \text { : Jumlah Kuadrat Skor Y } \\ \sum \mathrm{XY} & \text { : Jumlah hasil skor X dan } \mathrm{Y}\end{array}$

Kemudian Analisis Reliabilitas Instrumen Tes, Tes dikatakan reliabel jika skor amatan mempunyai korelasi yang tinggi dengan skor yang sebenarnya. Pengujian reliabilitas tes bentuk uraian pada umumnya orang menggunakan sebuah rumus yang dikenal dengan nama rumus Alpha (Hamzah, 2014: 233). Adapun rumus dimaksud adalah:

Keterangan:

$$
r_{11}=\left(\frac{k}{k-1}\right)\left(1-\frac{\sum \partial b^{2}}{\partial t^{2}}\right)
$$

$$
\begin{array}{ll}
r_{11} & : \text { Koefisien reliabilitas } \\
\mathrm{n} & : \text { Banyaknya siswa } \\
\mathrm{k} & : \text { Banyaknya item pertanyaan } \\
\partial t & : \text { Varians total } \\
\partial b & : \text { Varians butir }
\end{array}
$$

Analisis tingkat kesukaran instrument tes, cara menghitung tingkat kesukan untuk soal uraian adalah mengitung rata rata skor untuk tiap butir soal kemudian menghitung tingkat kesukarannya. Rumus yang digunakam yaitu:

$$
\begin{gathered}
\text { Rata-Rata }=\frac{\text { Jumlah skor peserta didik tiap soal }}{\text { Jumlah peserta didik }} \\
\text { Tingkat kesukaran }=\frac{\text { Rata }- \text { rata }}{\text { Skor Maksimum }}
\end{gathered}
$$

\section{HASIL DAN PEMBAHASAN PENELITIAN}

Pada pengembangan instrumen tes kemampuan untuk mengukur kemampuan pemecahan masalah (problem solving) ini disesuaikan dengan model pengembangan tipe formative research Tessmer. Model ini memiliki 4 tahapan yang telah ditentukan sebelumnya. 
3911 Pengembangan Instrumen Tes untuk Mengukur Kemampuan Problem Solving Siswa pada Materi Aritmatika Sosial - Nur Yuliani, Sitti Mania, Dian Magfirah, Fitriani Nur, Suharti

DOI: https://doi.org/10.31004/edukatif.v3i6.1226

\section{Tahap Preliminary}

Tahapan ini dimulai dengan pengumpulan beberapa referensi yang berhubungan dengan penelitian pengembangan ini. Setelah beberapa teori dan referensi sudah terkumpul, selanjutnya akan dilakukan kegiatan penentuan tempat dan subjek penelitian. Penentuan tempat dilakukan dengan cara menghubungi kepala sekolah dan guru mata pelajaran matematika di sekolah yang akan dijadikan lokasi uji coba. Selanjutnya peneliti akan melakukan wawancara kepada guru matematika yang bersangkutan mengenai kurikulum pembelajaran yang diterapkan di sekolah serta wawancara tentang bagaimana cara mengukur kemampuan siswa di sekolah.

\section{Tahap Self Evaluation}

Pada tahap self evaluation dilakukan penilaian oleh diri sendiri terhadap desain instrument tes kemampuan problem solving yang akan dibuat oleh peneliti. Tahapan ini terdiri dari dua kegiatan yaitu tahap analisis dan tahap mendesain. Pada tahap analisis, terdiri dari analisis kurikulum, analisis peserta didik, dan analisis materi. Analisis kurikulum; Kegiatan analisis kurikulum ini bertujuan untuk menetapkan masalah dasar yang diperlukan dalam mengembangkan instrumen tes. Kurikulum yang ditelaah adalah kurikulum yang digunakan di sekolah yaitu kurikulum 2013 mengenai standar kompetensi lulusan dan standar isi pendidikan dasar (SMP/MTs/SMPLB/Paket.

Tabel 1. Standar Kompetensi Lulusan dan Standar Isi Pendidikan Dasar (SMP/MTs/SMPLB/Paket B)

\begin{tabular}{ll}
\hline Standar Kompetensi Lulusan (SKL) & Memiliki keterampilan berpikir dan bertindak: \\
a. Kreatif; \\
b. Produktif; \\
c. Kritis; \\
d. Mandiri; \\
e.Kolaboratif; \\
f. Komunikatif \\
Melalui pendekatan ilmiah sesuai dengan yang \\
dipelajari di satuan pendidikan dan sumber lain \\
secara mandiri \\
Menunjukkan keterampilan menalar, mengolah, \\
dan menyaji secara: \\
a. Kreatif; \\
b. Produktif; \\
c. Kritis; \\
d. Mandiri; \\
e. Kolaboratif; \\
f. Komunikatif \\
Dalam ranah konkret dan ranah abstrak sesuai \\
dengan yang dipelajari di sekolah dan sumber \\
lain yang sama dalam sudut pandang teori \\
\hline
\end{tabular}

Proses pembelajaran dan standar pada kurikulum 2013 bertujuan untuk meningkatkan kemampuan berpikir peserta didik khususnya kemampuan berpikir tingkat tinggi (High Order Thinking Skill). Dalam standar kurikulum, peserta 47 didik harus memiliki dan menunjukkan keterampilan menalar dan mengolah salah satunya secara kritis. Butterworth dan Thawaites mengemukakan bahwa keterampilan pemecahan masalah termasuk di dalamnya berpikir kritis yang merupakan suatu aktifitas penggunaan logika yang digunakan untuk mengatasi berbagai kesulitan. Dengan demikian, keterampilan pemecahan masalah harus dimiliki peserta didik karena merupakan bagian dari kemampuan berpikir yang dimaksudkan di dalam standar kurikulum 2013 
3912 Pengembangan Instrumen Tes untuk Mengukur Kemampuan Problem Solving Siswa pada Materi Aritmatika Sosial - Nur Yuliani, Sitti Mania, Dian Magfirah, Fitriani Nur, Suharti

DOI: https://doi.org/10.31004/edukatif.v3i6.1226

Analisis Peserta Didik; Kegiatan analisis peserta didik ini difokuskan pada kelas VIII karena telah mempelajari materi aritmatika sosial pada saat kelas VII semester genap. Pemilihan subjek uji coba dilakukan secara acak dan hanya pada satu kelas yaitu kelas VIII 9 yang berjumlah 38 peserta didik. Analisis dilakukan dengan memberi angket peserta didik dan wawancara guru. Analisis peserta didik menggunakan angket dilakukan sebelum mengembangankan instrumen untuk mengetahui pemahaman peserta didik mengenai materi aritmatika sosial. Melalui angket yang disebar kepada 38 peserta didik kelas VIII 9, diperoleh hasil analisis angket peserta didik menunjukkan bahwa rata rata peserta didik mengetahui dengan baik manfaat mempelajari aritmatika sosial tetapi tidak memahami konsep materi. Berdasarkan jawaban dari pernyataan tentang bentuk soal, peserta didik lebih senang menggunakan bentuk soal pilihan ganda dibanding soal uraian, hal ini menunjukkan peserta didik memang tidak terbiasa untuk membuat suatu argumen. Wawancara yang dilakukan pada guru untuk memperoleh informasi peserta didik yang berkemampuan tinggi, berkemampuan sedang, dan berkemampuan rendah berdasarkan nilai UTS, UAS atau penilaian tersendiri dari 48 guru, sehingga diperoleh data 10 peserta didik berkemampuan tinggi, 20 peserta didik berkemampuan sedang dan 8 peserta didik berkemampuan rendah.

Analisis materi; merupakan kegiatan mengidentifikasi konsep-konsep yang digunakan dalam membuat instrumen tes. Berdasarkan analisis kurikulum yang telah dilakukan, materi yang digunakan dalam pengembangan instrumen tes sesuai dengan kurikulum 2013 kelas VII untuk konsep aritmatika sosial. Analisis dilakukan dengan menganalisis buku yang digunakan oleh guru dengan melihat indikator pembelajaran yang harus dicapai pada materi aritmatika social. Analisis dilakukan dengan menganalisis buku yang digunakan oleh guru dengan melihat indikator pembelajaran yang harus dicapai pada materi aritmatika sosial. Berikut ini tabel indikator pencapaian kompetensi

Tabel 2. Indikator Pencapaian Kompetensi

\begin{tabular}{ll}
\hline \multicolumn{1}{c}{ Indikator } \\
\hline 1. Mengetahui fenomena atau kegiatan yang berkaitan aritamatika sosial. \\
2. Menemukan fakta yang berkaitan dengan aritmatika sosial. \\
3. Menentukan keterkaitan antara untung, rugi penjualan, dan pembeliani \\
4. Menentukan pajak dan bunga tunggal \\
5. Menentukan keterkaitan bruto, neto dan tara. \\
6. Memecahkan permasalahan yang berkaitan aritmatika sosial, baik melalui \\
diskusi, presentasi ataupun tanya jawab. \\
\hline
\end{tabular}

Dari 6 indikator tersebut, item 3,4 dan 5 merupakan indikator dari Kompetensi Dasar 3.9 yang digunakan sebagai acuan dalam membuat indikator soal.

Selanjutnya yaitu mendesain instrumen tes dalam memecahkan masalah (problem solving), yang berkaitan dengan: kisi-kisi penyusunan instrumen tes, soal tes, kunci jawaban dan pedoman penskoran. Soal tes dibuat berpedoman pada indikator pembelajaran, materi yang dianalisis, dan indikator kemampuan pemecahan masalah (problem solving). Hasil rancangan instrumen tes berupa prototype I sebanyak 30 soal uraian, dan setiap soal mengandung indikator kemampuan pemecahan masalah (problem solving) yang diantaranya: mengetahui permasalahan, membuat taktik, menjalankan taktik, dan meninjau ulang. Soal-soal tes berupa situasi dan permasalahan yang bersifat kontekstual. Penampilan gambar yang ada pada soal dirancang agar soal tersebut menarik serta dapat berfungsi dengan baik. Lain dari hal tersebut, kunci jawaban dan pedoman dalam menilai dibuat untuk mempermudah pemberian skor terhadap hasil tes peserta didik. Fokus pada ketiga karakteristik yaitu : konten, konstruks dan Bahasa. Uraian ketiga karakteristik tersebut adalah sebagai berikut: 
3913 Pengembangan Instrumen Tes untuk Mengukur Kemampuan Problem Solving Siswa pada Materi Aritmatika Sosial - Nur Yuliani, Sitti Mania, Dian Magfirah, Fitriani Nur, Suharti

DOI: https://doi.org/10.31004/edukatif.v3i6.1226

Tabel 3. Uraian karakteristik

\begin{tabular}{ll}
\hline \multirow{3}{*}{ Konten } & Soal evaluasi dengan materi matematika \\
& kelas VII SMP semester genap \\
& Maksud soal dirumuskan dengan singkat dan \\
& jelas \\
& Soal sesuai dengan teori yang mendukung \\
& indikator \\
& Persoalan yang disajikan ialah soal-soal \\
& keterampilan memecahkan masalah \\
& Persoalan yang disajikan sesuai dengan \\
& tingkatan siswa \\
& Sesuai EYD \\
& Kalimat soal tidak ambigu \\
& Kalimat soal komunikatif menerapkan bahasa \\
& sederhana serta mudah dipahami \\
\hline
\end{tabular}

Kemudian tahap prototyping. Tahap ini tujuannya untuk menghasilkan prototype II dengan berdasar pada hasil revisi dari expert review dan uji coba one to one yang diberikan secara paralel, dan hasil percobaan small group untuk menghasilkan prototype III. Pakar adalah teknik untuk memperoleh masukan atau saran dari para ahli untuk penyempurnaan instrument tes. Pada tahap uji coba pakar atau biasanya disebut uji validitas, produk yang telah didesain akan dicermati, dinilai dan dievaluasi oeh pakar atau ahli. Para pakar atau validator akan menelaah konten, konstruks dan Bahasa dari masing-masing prototype.

Berdasarkan hasil validasi dari validator peneliti akan melakukan analisis terhadap hasil tersebut. Jika hasil analisis menunjukkan:

1) Valid tanpa revisi, maka kegiatan selanjutnya adalah field test.

2) Valid dengan nada revisi, maka kegiatan selanjutnya adalah merevisi terlebih dahulu, kemudian langsung field test.

3) Tidak valid, maka dilakukan revisi sehingga diperoleh prototype baru, kemudian Kembali pada kegiatan expert review atau saran ahli.

Pada tahap ini, tanggapan dan saran dari para validator tentang desain yang telah dibuat ditulis pada lembar validasi sebagai bahan merevisi atau menyatakan bahwa instrument tes kemampuan pemecahan masalah (problem solving) tersebut valid atau tidak. Penilaian pakar berfungsi untuk melakukan penyempurnaan prototype. Validasi dilakukan dengan memberikan lembaran instrumen, kisi- kisi penyusunan instrumen, soal evaluasi, kunci jawaban dan 50 pedoman penskoran untuk validator. Validator terdiri dari 2 dosen pendidikan matematika Fakultas Tarbiyah dan Keguruan yaitu Sri Sulasteri, S.Si., M.Si. (Validator I) dan Andi Dian Angriani, S.Pd., M.Pd. (Validator II) serta 1 guru matematika SMPN 2 Sungguminasa yaitu Sitti Fatimah, S.Pd. (Validator III). Dari penilaian para validator, berikut hasil yang dapat di lihat pada table di bawah init:

Tabel 4. Penilaian Validator

\begin{tabular}{cc}
\hline Validator & Penilaian Validator \\
\hline Validator I & Instrumen tes layak untuk diujicobakan dengan revisi kecil \\
Validator II & Instrumen tes layak untuk diujicobakan dengan revisi kecil \\
Validator III & Instrumen tes layak diujicobakan tanpa revisi \\
\hline
\end{tabular}


3914 Pengembangan Instrumen Tes untuk Mengukur Kemampuan Problem Solving Siswa pada Materi Aritmatika Sosial - Nur Yuliani, Sitti Mania, Dian Magfirah, Fitriani Nur, Suharti

DOI: https://doi.org/10.31004/edukatif.v3i6.1226

Berdasarkan tabel 4, penilaian validator secara keseluruhan instrumen tes layak untuk diujicobakan tetapi dengan sedikit revisi kecil.

Tabel 5. Saran Validator

\begin{tabular}{cl}
\hline Validator & \multicolumn{1}{c}{ Saran Validator } \\
\hline Validator I & Uraikan KD menjadi beberapa indikator \\
& Beri keterangan sumber pada gambar \\
Validator II & Tambahkan sampul instrument \\
& Perbaiki kesalahan penulisan \\
Validator III & Perbaiki kesalahan penulisan \\
\hline
\end{tabular}

Berdasarkan tabel 5, saran validator akan dipakai untuk bahan pertimbangan dalam merevisi prototype I. Lalu ada one to one. Pada tahap ini, peneliti meminta 3 orang peserta didik sebagai testeer yang sebaya non subjek untuk menjawab tes yang telah didesain. Tiga orang siswa ini terdisi dari siswa yang memiliki kemampuan tinggi, kemampuan sedang dan siswa dengan kemampuan rendah. Ketiga siswa tersebut juga diminta komentar tentang keterbacaan soal yang telah dikerjakan. Komentar dan sara dari expert review serta data yang diperoleh dari uji coba one-to-one dijadikan acuan untuk merevisi intrumen. Hasil revisi menghasilkan prototype II. Instrumen tes yang telah didesain sebagai prototype I selanjutnya diujicobakan pada tahap one to one oleh 3 peserta didik kelas VIII SMPN 2 Sungguminasa. siswa diminta untuk mengerjakan soal kemudian diberikan angket respon. Data perhitungan angket respon siswa disajikan dalam tabel berikut:

Tabel 6. Data Perhitungan Angket Respon siswa pada Tahap One to one

\begin{tabular}{lcccccccc}
\hline \multirow{2}{*}{ Responden } & \multicolumn{7}{c}{ Pernyataan } \\
\cline { 2 - 9 } & P1 & P2 & P3 & P4 & P5 & P6 & P7 & P8 \\
\hline R1 & 3 & 5 & 5 & 3 & 4 & 3 & 4 & 4 \\
R2 & 3 & 5 & 5 & 3 & 5 & 3 & 4 & 4 \\
R3 & 3 & 4 & 3 & 3 & 1 & 2 & 5 & 5 \\
Jumlah & 9 & 14 & 13 & 9 & 10 & 8 & 13 & 13 \\
Persentase & $60 \%$ & $93 \%$ & $87 \%$ & $60 \%$ & $67 \%$ & $53 \%$ & $86 \%$ & $86 \%$ \\
\hline
\end{tabular}

Angket respon yang terdiri dari 8 pernyataan masing-masing memiliki persentase respon yang berbeda beda. Respon positif terbesar adalah $93 \%$ terdapat pada pernyataan nomor 2 tentang penggunaan bahasa yang komunikatif, sedangkan persentase respon terkecil terdapat pada pernyataan nomor 6 tentang tingkat kemudahan soal.

Revisi dari expert review dan one-to-one kemudian di ujicobakan pada small group (6 orang siswa yang sebaya tetapi nonsubjek). Karakteristik siswa terdiri dari dua siswa dengan kemampuan tinggi, dua siswa dengan kemampuan sedang dan dua siswa dengan kemampuan rendah. Berdasarkan hasil hasil tes dan komentar siswa inilah produk direvisi dan diperbaiki Kembali. Hasil dari tahap ini diharapkan mengahasilkan instrument tes yang mampu mengukur kemampuan problem solving siswa. Desain instrument tes yang direvisi setelah tahap ini menghasilkan prototype III. 
3915 Pengembangan Instrumen Tes untuk Mengukur Kemampuan Problem Solving Siswa pada Materi Aritmatika Sosial - Nur Yuliani, Sitti Mania, Dian Magfirah, Fitriani Nur, Suharti

DOI: https://doi.org/10.31004/edukatif.v3i6.1226

\section{Tahap Uji Coba Lapangan}

Pada tahap imi hasil revisisi dari prototype II diujicobakan pada subjek uji coba penelitian dalam hal ini sebagai field test, yaitu siswa kelas VIII 9 SMPN 2 Sungguminasa dengan jumlah responden 38 siswa. Sebelum diujikan, produk terlebih dulu melalui proses validasi. Validator atau ahli diminta untuk memberikan penilaian terhadap semua instrument tes yang dikembangkan pada prototype I yang memuat konten konstruksi, Bahasa soal, alokasi waktu pengerjaan dan petunjuk yang ada dalam instemen. Adapun kriteria acuan untuk validasi adalah:

Tabel 7: Kriteria Kevalidan Instrumen oleh Ahli

\begin{tabular}{cc}
\hline Nilai & Kategori \\
\hline $\mathrm{V}>0,8$ & Sangat Valid \\
$0,4<\mathrm{V} \leq 0,8$ & Valid \\
$\mathrm{V} \leq 0,4$ & Kurang \\
\hline
\end{tabular}

Nilai indeks validitas yang berada dibawah 0,4 termasuk dalam kategori kurang sedangkan nilai indeks validitas diatas 0,8 termasuk dalam kategori sangat valid. Validasi dilakukan oleh 3 ahli yaitu 2 dosen dari jurusan pendidikan matematika dan 1 guru matematika memuat beberapa aspek yaitu aspek 52 isi, konstruk dan bahasa. Hasil analisis validasi instrumen yang diperoleh ditampilkan pada table di bawah ini:

Tabel 8. Hasil Analisis Validasi oleh Ahli

\begin{tabular}{|c|c|c|c|c|}
\hline Aspek & Indikator & $\mathbf{S}$ & $\mathbf{V}$ & Keterangan \\
\hline \multirow{4}{*}{ Isi } & $\begin{array}{l}\text { Kesesuaian butir soal dengan materi yang } \\
\text { diajarkan }\end{array}$ & 9 & 0,75 & Valid \\
\hline & $\begin{array}{l}\text { Kesesuaian butir soal dengan indikator } \\
\text { kemampuan pemecahan masalah }\end{array}$ & 11 & 0,92 & Valid \\
\hline & $\begin{array}{l}\text { Poin soal yang disajikan setara dengan skill } \\
\text { kemampuan peserta didik }\end{array}$ & 10 & 0,83 & Valid \\
\hline & Butir soal yang diujikan benar secara konsep & 9 & 0,75 & Valid \\
\hline \multirow{4}{*}{ Konstruk } & $\begin{array}{l}\text { pertanyaan memakai kata-kata tanya ataupun } \\
\text { perintah yang menuntut jawaban terurai }\end{array}$ & 8 & 0,66 & Valid \\
\hline & $\begin{array}{l}\text { Terdapat petunjuk jelas mengenai cara } \\
\text { mengerjakan soal dan mudah dipahami } \\
\text { peserta tes }\end{array}$ & 12 & 1,00 & Valid \\
\hline & $\begin{array}{l}\text { Keterangan dalam soal ditampilkan dengan } \\
\text { jelas }\end{array}$ & 9 & 0,75 & Valid \\
\hline & $\begin{array}{l}\text { Rumusan soal yang diujikan tidak bergantung } \\
\text { dalam jawaban soal sebelumnya }\end{array}$ & 9 & 0,75 & Valid \\
\hline \multirow[b]{2}{*}{ Bahasa } & Ketepatan struktur kalimat & 9 & 0,75 & Valid \\
\hline & Keefektifan kalimat & 9 & 0,75 & Valid \\
\hline
\end{tabular}


3916 Pengembangan Instrumen Tes untuk Mengukur Kemampuan Problem Solving Siswa pada Materi Aritmatika Sosial - Nur Yuliani, Sitti Mania, Dian Magfirah, Fitriani Nur, Suharti

DOI: https://doi.org/10.31004/edukatif.v3i6.1226

\begin{tabular}{lcccc}
\hline Kebakuan istilah & 9 & 0,75 & Valid \\
Soal tidak memiliki makna ganda & 8 & 0,66 & Valid \\
Kalimat yang digunakan mudah dipahami & 12 & 1,00 & Valid \\
Kemampuan memotivasi peserta didik & 8 & 0,66 & Valid \\
$\begin{array}{l}\text { Kesesuaian dengan tingkat perkembangan } \\
\text { emosional peserta didik }\end{array}$ & 9 & 0,75 & Valid \\
$\quad$ Rata-rata & & & 0,78 & Valid \\
\hline
\end{tabular}

Hasil analisis data uji validasi oleh ahli menunjukkan bahwa instrumen tes termasuk dalam kategori valid baik aspek isi, konstruk dan bahasa dengan koefisien validitas sebesar 0,78 yang berada pada rentan nilai $0,4<V \leq 0,8$. Hasil analisis respon siswa pada instrumen tes kemampuan pemecahan masalah dalam uji coba one to one dapat dilihat dalam table di bawah ini:

Tabel 9. Hasil Analsisi respon peserta Didik Tahap One To One

\begin{tabular}{ccccc}
\hline Responden & Skor & Skor Max & \% & Keterangan \\
\hline R1 & 26 & 40 & $65 \%$ & Cukup \\
R2 & 31 & 40 & $78 \%$ & Positif \\
R3 & 32 & 40 & $80 \%$ & Positif \\
Jumlah & 89 & 120 & $74 \%$ & Positif \\
\hline
\end{tabular}

Tabel 9 menunjukkan pada tahap one to one persentase rata-rata respon siswa yaitu $74 \%$ yang berada pada kriteria $70 \% \leq \mathrm{RS}<85 \%$ dengan penafsiran siswa memberikan respon yang baik pada instrumen tes yang telah dikerjakan. Kritik dan saran peserta didik pada uji coba one to one adalah sebagai berikut:

1. 3 dari 3 peserta didik menyatakan bahwa jumlah soal yang diberikan terlalu banyak.

2. 1 dari 3 peserta didik menyatakan waktu pengerjaan soal yang disediakan tidak sesuai dengan jumlah soal.

3. 1 dari 3 peserta didik menyatakan terdapat pernyataan yang kurang dipahami.

Respon peserta didik tersebut selanjutnya digunakan bahan untuk mengadakan perbaikan terhadap prototype I sehingga diperoleh produk instrumen yang telah direvisi. Proses pengembangan telah melalui serangkaian fase pengembangan model Tessmer. Produk akhir yang dihasilkan berupa instrumen tes berisi soal yang bisa digunakan dalam mengukur kemampuan pemecahan masalah (problem solving) siswa dengan memakai indikator kemampuan xalam memecahkan masalah menurut George Polya. Sebelum kegiatan pengembangan berlangsung, telah disetujui kriteria kualitas instrumen tes untuk mengukur keberhasilan produk yang diciptakan.

Adapun instrumen tes yang telah dihasilkan memiliki spesifikasi setiap butir soal memuat 4 indikator kemampuan pemecahan masalah (problem solving), setiap butir masalah yang dimunculkan mencakup kegiatan jual beli pada kehidupan hari-hari yang sesuai dengan tingkat kemampuan jenjang SMP sehingga dalam menyelesaikan permasalahan bersifat kontekstual.

Berdasarkan hasil analisis validitas oleh validator, diperoleh instrumen tes yang memuat 30 soal uraian yang dikembangkan dalam aspek isi, konstruk dan bahasa termasuk dalam kategori layak digunakan untuk mengukur kemampuan pemecahan masalah siswa. Sementara itu, angket respon peserta didik pada tahap one 
3917 Pengembangan Instrumen Tes untuk Mengukur Kemampuan Problem Solving Siswa pada Materi Aritmatika Sosial - Nur Yuliani, Sitti Mania, Dian Magfirah, Fitriani Nur, Suharti

DOI: https://doi.org/10.31004/edukatif.v3i6.1226

to one juga menunjukkan respon yang positif terhadap keterbacaan soal. Instrumen yang dikembangkan dengan jumlah soal yang ada memerlukan alokasi waktu yang lama bagi peserta didik agar bisa menuntaskan instrumen tes. Karena keterbatasan, produk yang dikembangkan juga belum melalui tahap field test sehingga kriteria kualitas instrumen dari tingkat kesukaran, daya pembeda, keefektifan penggunaan instrument test dan segi reliabilitas belum dapat diketahui.

\section{KESIMPULAN}

Dari hasil pengembangan instrumen tes kemampuan pemecahan masalah (problem solving) dapat disimpulkan bahwa proses pengembangan instrumen tes terdiri dari empat tahapan yaitu, tahap preliminary, tahap self evaluation, tahap prototyping dan tahap field test. Tetapi peneliti hanya melalui 3 tahapan yaitu sampai tahap prototyping. Hasil instrumen tes yang sudah dikembangkan dalam tahap uji validasi oleh ahli memenuhi kriteria valid dengan nilai koefisien validitas sebesar 0,78 . Berdasarkan analisis angket respon peserta didik di tahap one to one diperoleh hasil bahwa peserta didik memberikan persentase respon sebesar 74\% pada instrumen tes yang telah dikembangkan sedangkan hasil angket respon guru diperoleh persentase sebesar $83 \%$. Berdasarkan hasil respon tersebut, kriteria kepraktisan instrumen tes yang dikembangkan termasuk dalam kategori positif.

Dari hasil yang didapatkan dari penelitian, dapat dipaparkan beberapa saran yaitu : Dalam mengembangkan kemampuan pemecahan masalah (problem solving) peserta didik disarankan agar lebih sering menyelesaikan soal yang menuntut untuk berpikir memecahkan suatu masalah. Agar dapat mengetahui lebih lanjut baik atau tidaknya instrumen tes yang sudah dikembangkan, oleh karena itu disarankan agar peneliti selanjutnya mengujicobakan di subjek yang lebih luas.

\section{DAFTAR PUSTAKA}

Angriani, Andi Dian, Dkk. (2018). "Pengembangan Instrumen Tes Untuk Mengukur Kemampuan Pemecahan Masalah Matematika Siswa. Jurnal Pendidikan Dasar Islam.

Arifin, Z. (2013). Evaluasi Pembelajaran. PT Remaja Rosdakarya.

Astuti, W. (2019). Pengembangan Instrumen Tes Keterampilan Berpikir Kritis Pada Konsep Fungi. Universitas Islam Negeri Syarif Hidayatullah.

Butterworth, J. Dan G. T. (2013). Thinking Skills Critical Thinking And Problem Solving. Cambridge University Press.

Hidayat, Syarif Rokhmat, D. (2017). Pengembangan Instrumen Tes Keterampilan Pemecahan Masalah Pada Materi Getaran, Gelombang, Dan Bunyi. Jurnal Penelitian \& Pengembangan Pendidikan Fisika.

Hidayat, R. (2016). Analisis Level Kognitif Soal-Soal Pemecahan Masalah Pada Buku Siswa Matematika Kelas VIII Kurikulum 2013. Universitas Muhammdiyah Surakarta.

Kemendikbud. (2013). Peraturan Mentri Pendidikan Dan Kebudayaan Nomor 65, Tahun 2013, Tentang Standar Proses.

Masfuah, S. Dan I. A. P. (2018). Pentingnya Kemampuan Pemecahan Masalah Dan Karakter Bersahabat. Prosiding Seminar Nasional.

Mulyadi. (2010). Pengembangan Model Evaluasi Pendidikan Agama Di Sekolah. Malang: UIN- MALIKI Press.

Nursalam. (2016). Diagnostik Kesulitan Belajar Matematika: Studi Pada Siswa SD/MI Di Kota Makassar. Lentera Pendidikan. 
3918 Pengembangan Instrumen Tes untuk Mengukur Kemampuan Problem Solving Siswa pada Materi Aritmatika Sosial - Nur Yuliani, Sitti Mania, Dian Magfirah, Fitriani Nur, Suharti

DOI: https://doi.org/10.31004/edukatif.v3i6.1226

Polya, G. (1945). How To Solve It. Princeton University Press.

Putra, N. (2015). Research \& Development Penelitian Dan Pengembangan: Suatu Pengantar. Jakarta: Rajawali Pers.

Sagita, I., Medriati, R., \& Puerwanto, A. (2018). Penerapan Creative Problem Solving Model Untuk Meningkatkan Kemampuan Pemecahan Masalah Fisika Siswa Kelas XI MIA 4 MAN 2 Kota Bengkulu. Kumparan Fisika, 1(3), 1-6.

Sudijono, A. (2008). Pengantar Evaluasi Pendidikan. Jakarta : Raja Grafindo Persada.

Sumardoyo. (2010). Pengertian Dasar Problem Solving.

Sumartini, T. S. (2016). Peningkatan Kemampuan Pemecahan Masalah Matematis Siswa Melalui Pembelajaran Berbasis Masalah. Jurnal Mosharafa, 5(2), 148-158 Https://Doi.Org/Https://Doi.Org/10.31980/Mosharafa.V5i2.270

Sutarno, S., Setiawan, A., Karniawati, I., \& Suhandi, A. (2017). Pre-Service Physich Teacher' ProblemSolving Skills In Projectile Motion Concept. Journal Of Phsics: Conference Series, 895(1).

Syaharuddin. (2016). Deskripsi Kemampuan Pemecahan Masalah Matematika Dalam Hubungannya Dengan Pemahaman Konsep Ditinjau Dari Gaya Belajar Siswa Kelas VIII SMPN 4 Binamu Kabupaten Jeneponto. Universitas Negeri Makassar.

Syahruddin. (2016). Deskripsi Kemampuan Pemecahan Masalah Matematika Dalam Hubungannya Dengan Pemahaman Konsep Ditinjau Dari Gaya Belajar Siswa Kelas VII SMPN 4 Binamu Kabupaten Jeneponto. Universitas Negeri Makassar.

Tessmer, M. (1993). Planning And Conducting Formative Evaluations: Improving The Quality. Kogan Page.

Wahyuningrum, E. Dan Y. (2015). Pembelajaran ICARE (Inroduction, Connect, Apply, Reflect, Extend) Dalam Tutorial Online Untuk Meningkatkan Kemampuan Pemecahan Masalah Matematis Mahasiswa UT. Jurnal Ilmiah Program Studi Matematika STKIP Siliwangi Bandung.

Wulandari, R. (2017). Analisis Tingkat Kesulitan Soal Pemecahan Masalah Dalam Buku Siswa Pelajaran Matematika SMP Kelas VII Kurikulum 2013. Universitas Muhammadiyah Surakarta. 